\title{
Analysis on Phases of Globalization and Convergence
}

\author{
Bin Tang ${ }^{1, ~ *, ~ G u a n m i n j i a ~ S h a n g ~}{ }^{1}$, Anli Leng ${ }^{2}$, Ningning Yu ${ }^{3}$ \\ ${ }^{1}$ Center for Experimental Economics in Education, Shaanxi Normal University, Xi'an, China \\ ${ }^{2}$ Department of Social Medicine, School of Public Health, Shandong University, Jinan, China \\ ${ }^{3}$ Institute of Higher Education Research, University of Jinan, Jinan, China
}

\section{Email address:}

tangbin198994@163.com(Bin Tang), shangguanceee@163.com(Guanminjia Shang), anlijiayou@163.com(Anli Leng), yuning7412@126.com (Ningning Yu)

${ }^{*}$ Corresponding author

\section{To cite this article:}

Bin Tang, Guanminjia Shang, Anli Leng, Ningning Yu. Analysis on Phases of Globalization and Convergence. Journal of World Economic Research. Vol. 7, No. 1, 2018, pp. 37-43. doi: 10.11648/j.jwer.20180701.14

Received: March 6, 2018; Accepted: March 21, 2018; Published: April 11, 2018

\begin{abstract}
Globalization, along with many conceptual notions, such as economic growth, convergence has involved a mass of research works, but remains disputable based on miscellaneous samples and periods. This paper aims to discuss to what extent two phases of globalization are similar in the light of convergence and variants. With methods of historical analysis and empirical evidence synthesis, we find the first and second phases of globalization have common features on remarkable economic growth, transport costs' decline and free and flexible trade policy, but the range and extent are moderately different. Additionally, the two phases of globalization have various convergence paths. Some new perspectives such as social and political dimensions and policy implications have been referred to.
\end{abstract}

Keywords: Globalization, Convergence, Factors

\section{Introduction}

Globalization, from the economic perspective, known as "a movement towards neoliberal economic policy reforms and an increase in the worldwide movement of capital, goods, services and labour" [1], can be tracked back in the $19^{\text {th }}$ century. The first phase of globalization (G1) was defined from 1850 to 1914 , due to the interwar period of 1914-1945, after which there is the second phase of globalization (G2) dating from 1950 till now [2]. Convergence, originally detected among "Atlantic economies" (also called OECD countries), indicating that economies with varied levels and situations can move towards a point from different directions and meet or reach the same level, is bound up with the evolution of globalization [3, 4]. Specifically, the New World, known as U.S. and European countries converged on the issue of trade expansion, commodity prices, real wages, etc. during the rounds of globalization and globalization has been considered as "the leading to the erosion and lessening of national differences" [5]. The extent and corresponding periods, nevertheless, vary from patterns or economies [6]. Each stage is seen as a prerequisite for the next stage, as new political, economic and social institutions should enable more advanced and differentiated activities in the future [7].

The overall structure has been outlined as follows: some primary reasons for convergence will be presented in section 2; compared with the first phase of globalization, section 3 focuses on the similarity and difference of the second epoch; finally, policy implication and conclusion regarding globalization with convergence would be deduced reasonably and soundly.

\section{Principal Factors of Convergence in the First Phase of Globalization}

According to O'Rourke and Williamson (2001), “G1 involved the most extensive real wage and living standard convergence OECDs have witnessed" [8]. The average wage gap between the New World and Europe takes up $60 \%$ of the real wage variance and $40 \%$ scattering in Europe (Figure 1). $60 \%$ of the real wage convergence can be accounted for the narrowing and elimination of wage gap. Several principal factors of convergence will be examined. 


\section{Measures of real wage dispersion 1854-1914 (O\&W Fig 2.2, p. 15)}

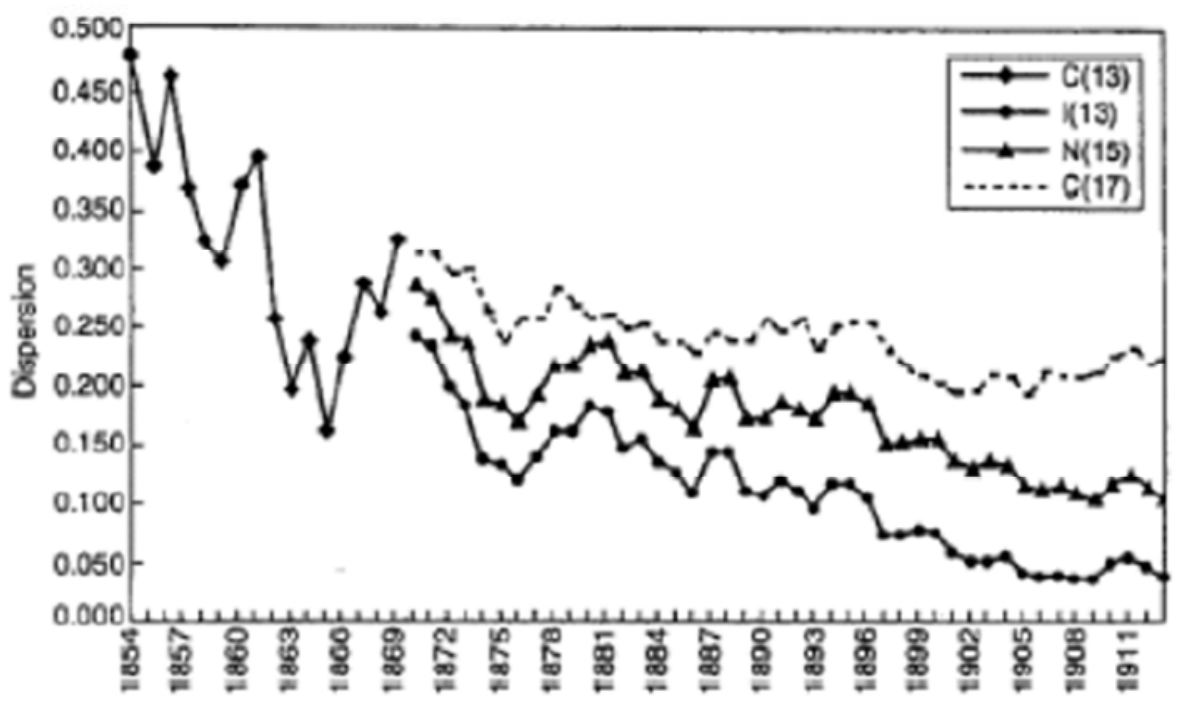

(Source: O'Rourke, K. H. and J. G. Williamson. (2001). Globalization and history: the evolution of a nineteenth-century Atlantic economy, MIT press.)

Figure 1. Measure of real wage dispersion.

Many research results have identified the decrease of transport costs derived from technological progress as the main cause of convergence [8-11]. Based on Slow Model Theory, one economy's success can be largely resulted from the contribution of Total Factor Productivity. UK and other European countries took advantage of production efficiency and relatively advanced technology to reduce the money and time of transporting goods across borders, such as the techniques of steamship, railway expansion, and refrigeration. It is estimated that transport costs fell by $1.5 \%$ per year from 1870 to 1913 and $45 \%$ totally [8]. In addition, confronted with fierce competition from South American and Australian, European economies raised their import demands of scanty foodstuffs. These stimulate them to circulate commodity between the New World and Europe, alleviating the gap and promoting the consistence.

Apart from transport costs decline, O'Rourke and Williamson (2001), Williamson (2001) highlight the impact of liberal trade policy and loose legislation concerning trades unions [8, 10]. For example, after 1815, the UK and European countries began to dismantle some of trade barriers for the sake of funding initial losses (Figure 2). However, progress exhibited greater in small countries (Netherland, Denmark and Sweden) than most of Europe until the effects of Cobden-Chevalier Treaty between France and the UK in 1860 (Figure 3) and the Most-Favoured Nation Clause by which countries might extend trade concessions granted to third parties. Despite rise in tariffs, the overall effect of the free trade policy change tended to guide commodity prices to converge.

Timeline of UK pro-trade measures, $1825-46$

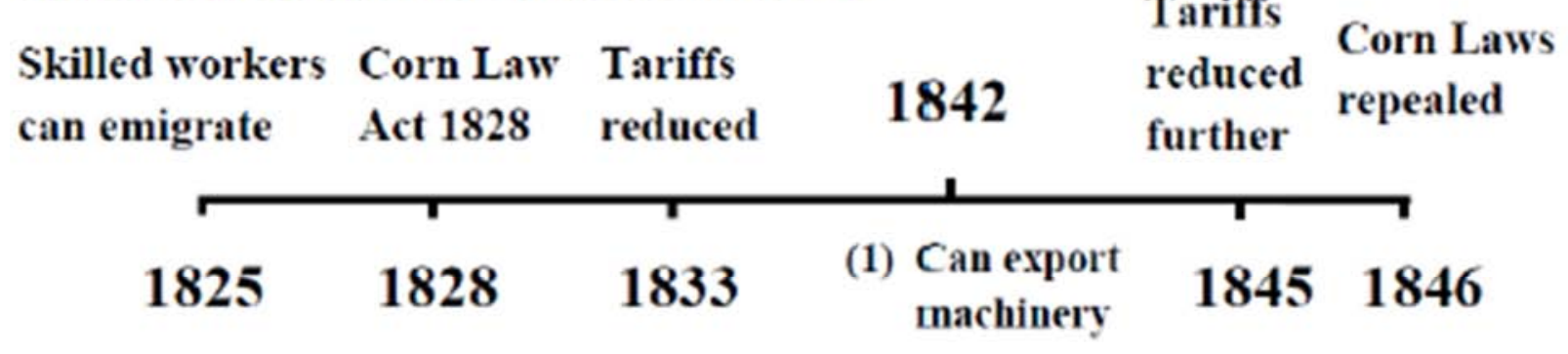

\section{(2) Wool export}

tax abolished

(Source: Hatcher, M. (2013). IMEP Lecture Notes 1-2. Available on Moodle of University of Glasgow.)

Figure 2. Timeline of UK pro-trade measures. 


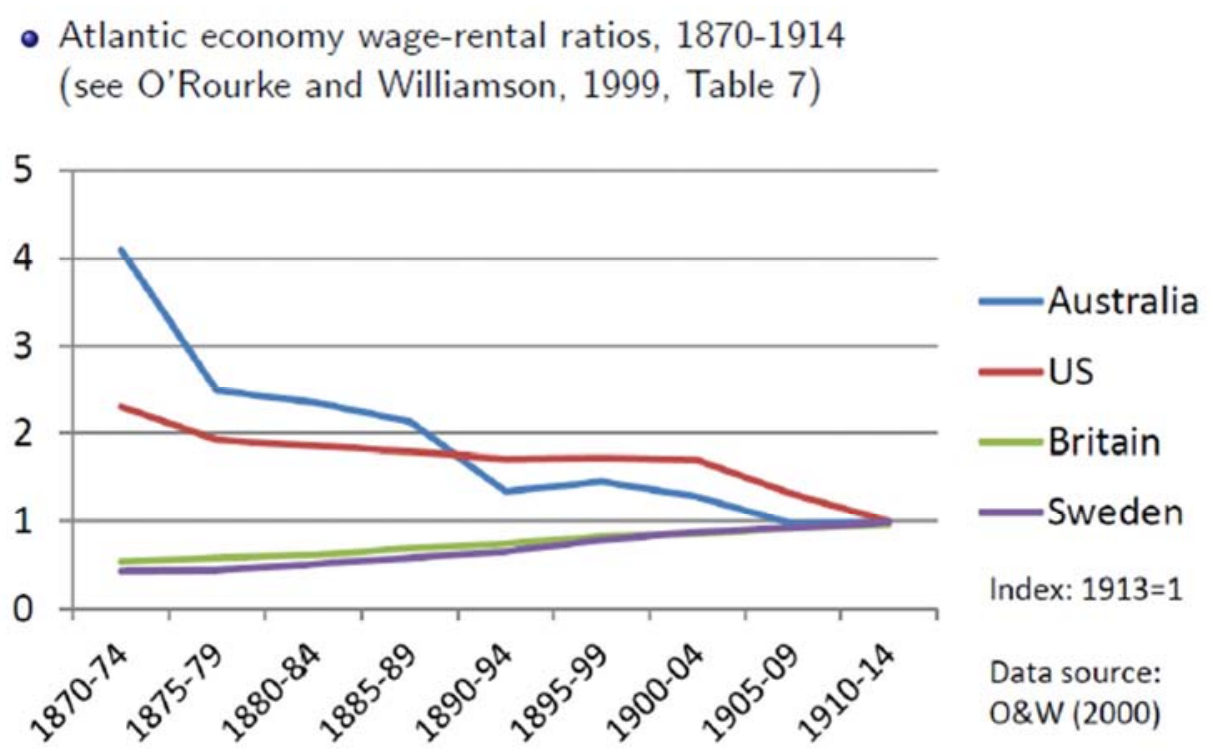

(Source: Hatcher, M. (2013). IMEP Lecture Notes 3-4. Available on Moodle of University of Glasgow.)

Figure 3. Atlantic economy wage-rental ratios.

More interestingly, factors also have negative influence on convergence. Transport costs decline gave rise to the increase of tariffs, which implies a distributional effect and protectionism. Free trade may bring about risks of being dependent on imports and threats and suppress on domestic emerging industries. Overall, research has revealed that decline on transport costs attached more significance to market integration and prices convergence than trade policy; however, both of them play a crucial role in the G1 convergence since the synthetic effect is in line with the Hechsher-Ohlin model shown in Figure 4 [2]:

$$
\left.\begin{array}{l}
\text { Transport costs } \downarrow \\
\text { Free trade }
\end{array}\right\} \rightarrow \text { Price convergence } \rightarrow \text { Factor price convergence }
$$

Figure 4. G1 convergence.

Applying H-O model to G1, the New World and Europe can be winners and losers in the light of their relatively comparative advantage as shown in Table 1.

Table 1. Winners\& Losers.

\begin{tabular}{ll}
\hline Winners & Losers \\
\hline New World land & European land \\
European labour & New World labour \\
\hline
\end{tabular}

The empirical study on Atlantic economy wage-rental ratios from 1870 to 1914 (Figure 3) reconfirmed real wage and price convergence, relative factor price convergence is consistent with $\mathrm{H}-\mathrm{O}$ model.

\section{Discussion of Convergence in the Second Phase of Globalization}

After the Great Reversal, the world has experienced another unpredictable integration and globalization since 1950. The G2 is more bewildering than G1 regarding the amount and sources of convergence.

\subsection{Basic Comparison of $G 1$ and $G 2$}

G1 and G2 are periods of trade expansion, substantial capital flows and massive migration. They have apparent features on remarkable economic growth, transport costs' decline and free and flexible trade policy, but the range and extent are moderately different. The following (Table 2) on the basis of research from Wolf (2001) and O'Rourke and Williamson (2001) [8, 9], demonstrates the variations between the two periods on convergence.

Table 2. Features of $G 1 \& G 2$.

\begin{tabular}{|c|c|c|}
\hline Features/ Phases & G1 & G2 \\
\hline Characteristic of convergence & $\begin{array}{l}\text { Concentrated convergence; } \\
\text { Shaking changes }\end{array}$ & Prosaically but internationally economic integration \\
\hline Transport costs' decline & More dramatically & Modest reduction \\
\hline Trade policy & More important than transport costs & $\begin{array}{l}\text { Play a bigger role than } \mathrm{G} 1 \text {; } \\
\text { Close relationship; } \\
\text { intra-industry trade in manufactures }\end{array}$ \\
\hline Capital flows & $\begin{array}{l}\text { Short-term: limited capital mobility and a few markets } \\
\text { Long-term: } \\
\text { Bound up with fixed exchange rate regime; } \\
\text { intangible investment; }\end{array}$ & $\begin{array}{l}\text { Short-term: more capital mobility and extensive markets } \\
\text { Long-term: } \\
\text { Debt financing; } \\
\text { more tangible assets; }\end{array}$ \\
\hline
\end{tabular}




\begin{tabular}{lll}
\hline Features/ Phases & G1 & G2 \\
\hline & mainly bonds; & bonds and stocks; \\
& portfolio flows took dominant role; & more direct investment; \\
& industrial free-standing companies & Multinational corporations \\
migration & massive & Obvious, but not remarkable \\
changes & Break trade barriers; & Rise of global institutions; \\
& Trade specialization & Rise of welfare state \\
\hline
\end{tabular}

\subsection{The Sources of Convergence and Diversity}

Compared with convergence in G1, G2 has witnessed relatively moderate convergence and has exhibited convergence in various aspects, not only being confined in real wages and commodity prices, but embodying a range of domains.

\subsubsection{Globalization and Inequality, Economic Growth and Migration}

Lindert and Williamson (2001) [12] have observed the relationship between globalization and inequality from different epochs (Figure5; Figure6). They found in G2, generically income gaps across participating countries have been lessened, and inequality within economies decreased, but disparity between certain countries went up more rapidly according to the division of labour intensity. The overall tendency is that inequality is meant to be narrowed with economic integration and segmentation, but it is argued that cross-country disparities will stay relatively high especially from social and political globalization perspectives [13]. With the deepening of globalization, the opinion that free trade and openness contributes to economic growth positively or "participation brings prosperity" has been acknowledged [14]; nonetheless, the reason why disparity between countries may become progressively larger lies in that the impacts of globalization exert distinctively on countries. For instance, Ding and Knight [15] [16] focus on the economic growth of China, compared with OECDs or other developing countries which have the same starting point, revealing that China benefits from the advantages of human capital, population growth, and physical investment along with the integration of world, only to achieve the growth miracle of $9.5 \%$ in average annual growth rate of GDP. The absolute level of migration in G2 assembles the case in G1, but convergence of G1 took much advantage of relative importance of migration in contrast with $\mathrm{G} 2$.

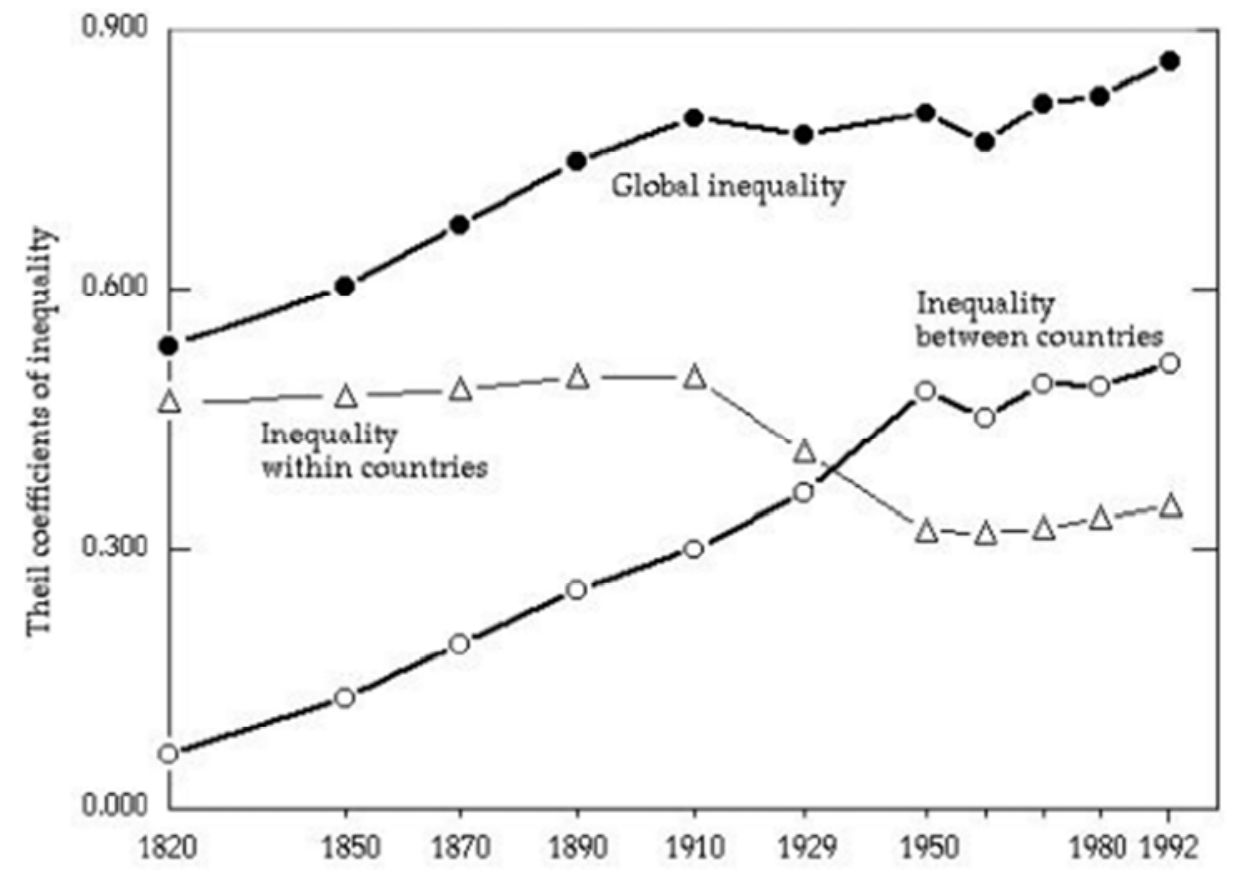

(Source: Hatcher, M.(2013). IMEP Lecture Notes 3-4. Available on Moodle of University of Glasgow.)

Figure 5. The efficiency of inequality. 


\begin{tabular}{|c|c|c|c|c|c|}
\hline \multirow[b]{2}{*}{ Epoch } & \multirow{2}{*}{$\begin{array}{l}\text { Global } \\
\text { inequality } \\
\text { trend }\end{array}$} & \multicolumn{2}{|c|}{ Inequality between nations } & \multicolumn{2}{|c|}{ Inequality within nations } \\
\hline & & Trend & $\begin{array}{l}\text { Effects of } \\
\text { globalization }\end{array}$ & Trend & $\begin{array}{l}\text { Effects of } \\
\text { globalization }\end{array}$ \\
\hline $1500-1820$ & $\begin{array}{l}\text { Rising } \\
\text { inequality }\end{array}$ & $\begin{array}{l}\text { Rising } \\
\text { inequality }\end{array}$ & No clear net effect. & $\begin{array}{l}\text { Rising } \\
\text { inequality } \\
\text { (W. Europe) }\end{array}$ & No clear net effect. \\
\hline $1820-1914$ & $\begin{array}{l}\text { Rising } \\
\text { inequality }\end{array}$ & $\begin{array}{l}\text { Rising } \\
\text { inequality }\end{array}$ & $\begin{array}{l}\text { Participants gain on } \\
\text { non-partic. countries. } \\
\text { Among participants, } \\
\text { migration reduced } \\
\text { ineq. more than capital } \\
\text { flows raised it. Freer } \\
\text { trade may have reduced } \\
\text { ineq., with exceptions. }\end{array}$ & $\begin{array}{l}\text { No clear } \\
\text { trend }\end{array}$ & $\begin{array}{l}\text { Globalization raised } \\
\text { inequality in the } \\
\text { New World, reduced } \\
\text { it in participating } \\
\text { Old World nations. }\end{array}$ \\
\hline $1914-1950$ & $\begin{array}{l}\text { No clear } \\
\text { inequality } \\
\text { trend }\end{array}$ & $\begin{array}{l}\text { Rising } \\
\text { inequality }\end{array}$ & $\begin{array}{l}\text { Retreat from globalization } \\
\text { widened the gaps } \\
\text { between nations. }\end{array}$ & $\begin{array}{l}\text { Falling } \\
\text { inequality } \\
\text { (in OECD) }\end{array}$ & No clear net effect. \\
\hline $1950-2000$ & $\begin{array}{l}\text { Slightly } \\
\text { rising } \\
\text { inequality }\end{array}$ & $\begin{array}{l}\text { Slightly } \\
\text { rising } \\
\text { inequality }\end{array}$ & $\begin{array}{l}\text { Globalized trade and } \\
\text { migration narrowed the } \\
\text { gaps among participants. } \\
\text { Non-participants fell } \\
\text { further behind. }\end{array}$ & $\begin{array}{l}\text { Slightly } \\
\text { rising } \\
\text { inequality } \\
\text { (in OECD) }\end{array}$ & $\begin{array}{l}\text { Globalization raised } \\
\text { inequality within } \\
\text { OECD countries. In } \\
\text { other countries, } \\
\text { non-participating } \\
\text { regions fell behind. }\end{array}$ \\
\hline
\end{tabular}

(Source: Hatcher, M.(2013). IMEP Lecture Notes 3-4. Available on Moodle of University of Glasgow.)

Figure 6. Global inequality.

\subsubsection{Globalization on Other Relevant and Diverse Aspects}

Studies are not restricted on OECDs, for example, Martin and Sunley (1998) [17] identified the slow and discontinuous convergence in regional development with exogenous growth model including the observations of developing countries. Villaverde and Maza (2011) [18] conducted regression with conventional $\sigma, \beta$ convergence incorporating 114 economies consisting of OECDs and developing countries from the period of 1970 to 2005 (Figure 7) indicting G2 has promoted growth and fostered income convergence all over the countries involved in globalization.

\section{Sigma ( $\sigma$ ) Convergence (Coefficient of Variation)}

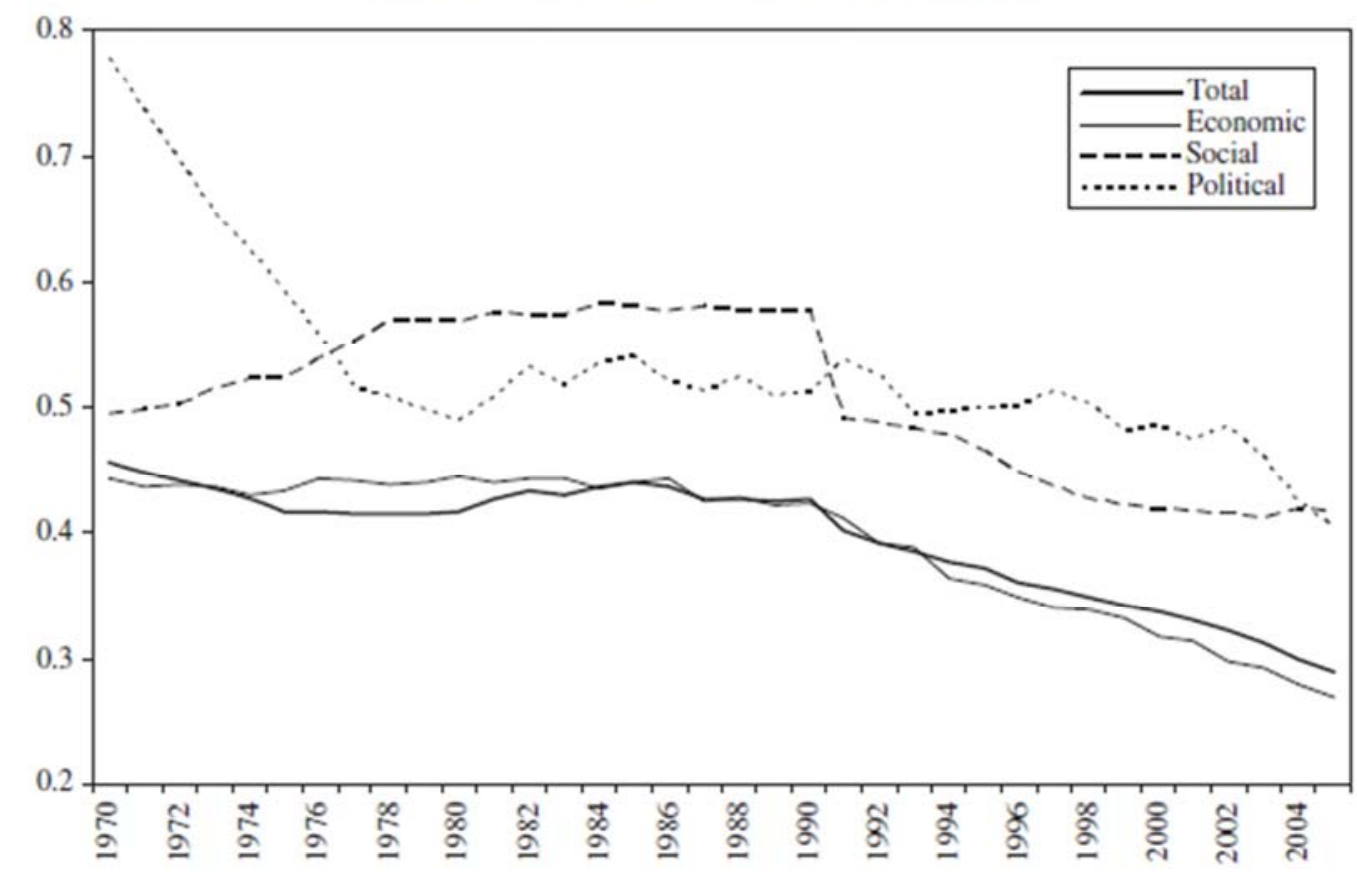


Beta $(\beta)$ Convergence

\begin{tabular}{|c|c|c|c|c|c|c|c|c|}
\hline & \multicolumn{2}{|l|}{ Total } & \multicolumn{2}{|c|}{ Economic } & \multicolumn{2}{|l|}{ Social } & \multicolumn{2}{|l|}{ Political } \\
\hline & Value & t-statistic & Value & \multirow{2}{*}{$\frac{t \text {-statistic }}{-9.91}$} & \multirow{2}{*}{$\frac{\text { Value }}{-0.064^{*}}$} & \multirow{2}{*}{$\frac{t \text {-statistic }}{-10.71}$} & \multirow{2}{*}{$\frac{\text { Value }}{-0.113^{*}}$} & \multirow{2}{*}{$\frac{t \text {-statistic }}{-23.03}$} \\
\hline & $-0.081^{*}$ & -11.90 & $-0.068^{*}$ & & & & & \\
\hline Adjusted $\mathrm{R}^{2}$ & & 0.37 & & 0.30 & & 0.42 & & .55 \\
\hline $\begin{array}{l}\text { Number of } \\
\text { countries }\end{array}$ & & 101 & & 101 & & 101 & & 101 \\
\hline $\begin{array}{l}\text { Number of } \\
\text { observations }\end{array}$ & & 707 & & 707 & & 707 & & 707 \\
\hline $\begin{array}{l}\text { Speed of } \\
\text { convergence } \\
\text { (5-years \%) }\end{array}$ & & 2.02 & & 9.16 & & 8.55 & & 2.25 \\
\hline $\begin{array}{l}\text { Half-life } \\
\text { (5-years periods) }\end{array}$ & & 8.2 & & 9.9 & & 10.4 & & 5.8 \\
\hline
\end{tabular}

(Source: Villaverde, J. and Maza, A. (2011). Globalisation, Growth and Convergence. The World Economy.)

Figure 7. Sigma and Beta convergence.

Though G2 has increased the scale and size of transactional capital flows, Drezner (2001) [19] finds little convergence on regulatory standards except for policy convergence significantly displaying on labour and environmental standards. However, Blank and Burau (2006) [20] testified that "with a co-existence of convergence and divergence, there are clusters of convergence primarily at the ideational and social value levels" rather than economic perspective. For example, the recognition of health, education, democracy [21] and women status [1] has been converged with the advancement of G2, which shows an identical sense of real wages and commodity prices in G1 but relatively weak convergence, but the policy adoptions are faced with problems and restricts due to the various background and institutional regimes. Achterberg and Yerkes (2009) [22] believe "countries are converging in the middle, with social democratic countries becoming more liberal and liberal countries becoming more social democratic" allowing for the welfare perspective. On the contrary, Khanna and Palepu (2004) [23], Dreher etal(2008) [24], Mishkin (2007) [25] reported that the convergence on corporate governance, government expenditures and financial services are limited in case of risks caused by globalization, such as financial crisis or chain effect and measures to resist the potential dangers of G2 on domestic economies should be implemented although welfare benefits may lose or citizens may suffer from kind of economic blockades.

Williamson (1996) [10], Vaio and Enflo (2011) [11] mentioned transport costs and trade policy are seemingly proximate factors to account for convergence in G1 as well as G2, and some fundamental causes or underlying factor including luck (or multiple equilibria), geographic and cultural differences, institutional variants are supposed to be considered and explored. Radice (2000) [5] thinks "globalization may be perceived as leading to convergence on a common institutional order". Globalization might be segmented and deepened in different types of institutional regimes. Developing a semi-global marketing strategy be advocated, which could generate "greater autonomy at the local level" [26].

\subsection{Policy Implication}

(1) If the maximization of economic efficiency is the ultimate target, the detrimental points of globalization towards language, education, democracy, national identity can be disregarded. However, actually, economic convergence and benefits of social or political dimensions have to be balanced by local governments, which will put policy makers in a dilemma.

(2) With the further convergence taking place in increasingly aspects, "the room for policy maneuvering is obviously reduced" [21], and market independence and autonomy intervention may be trapped, posing a tough choice in front of authorities.

(3) Global organizations should play a greater role and make more efforts to coordinate and control the convergence and drawbacks that will be crept into participating economies. However, historically, "policy co-ordination" [27] conducted by world organizations is hard to fulfill and maintain over long periods.

\section{Conclusion}

This paper has examined some prime factors of convergence with the first stage of globalization and discussed the complicated respects from convergence occurring in the second phase of globalization. More specifically, some new perspectives such as social and political dimensions and policy implications have been referred to. However, economic approaches to measuring 
globalization still remain to be indefinite provided that economic, social, and political perspectives are required to be included. Thus, policy makers in each economy may suffer bewilderment when making decisions to face up to the transformation of globalization and convergence.

\section{Acknowledgements}

The authors would like to acknowledge the funding support from the Fundamental Research Funds for the Central Universities (Grant No. 2017CBY017), National Natural Science Foundation of China (Grant No. 71703084), the National Science Foundation of China (Grant No. 17BJY201) and China Scholarship Council.

\section{References}

[1] Richards, D. L. and Gelleny, R. (2007). Women's Status and Economic Globalization. International Studies Quarterly, 51(4), pp. 855-876.

[2] Hatcher, M.(2013). IMEP Lecture Notes 1-5. Available on Moodle of University of Glasgow.

[3] Williamson, J. G.(1996). Globalization, Convergence, and History. The Journal of Economic History, 56(2), Papers Presented at the Fifty-Fifth Annual Meeting of the Economic History Association (Jun, 1996), pp. 277-306.

[4] Hendi, A. S. (2017). Globalization and Contemporary Fertility Convergence. Social Forces, 96(1), 215-238.

[5] Radice, H. (2000). Globalization and National Capitalisms: Theorizing Convergence and Differentiation. Review of International Political Economy, 7(4), pp. 719-742.

[6] Berry, H., Guillén, M. F., \& Hendi, A. S. (2014). Is there convergence across countries? A spatial approach. Journal of international business studies, 45(4), 387-404.

[7] Korotayev, A., Goldstone, J. A., \& Zinkina, J. (2015). Phases of global demographic transition correlate with phases of the Great Divergence and Great Convergence. Technological Forecasting and Social Change, 95, 163-169.

[8] O'Rourke, K. H. and J. G. Williamson. (2001). Globalization and history: the evolution of a nineteenth-century Atlantic economy, MIT press.

[9] Wolf, M. (2001). Is today's globalisation different from what has gone before? Manchester Statistical Society.

[10] Williamson, J. G. (2002). Winners and losers over two centuries of globalization. Available at http://www.wider.unu.edu/publications/annual-lectures/

[11] Vaio, G. and Enflo, K. (2011). Did globalization drive convergence? Identifying cross-country growth regimes in the long run. European Economic Review, 55, pp. 832-844.
[12] Lindert. P. H. \& Jeffrey G. Williamson, (2001). "Does Globalization Make the World More Unequal?," NBER Working Papers 8228.

[13] Baylis, J., Smith, S., \& Owens, P. (Eds.). (2017). The globalization of world politics: an introduction to international relations. Oxford University Press.

[14] Gurgul, H., \& Lach, Ł. (2014). Globalization and economic growth: Evidence from two decades of transition in CEE. Economic Modelling, 36, 99-107.

[15] Ding, S. and Knight, J. (2009). Can the augmented Solow model explain China's economic growth? A cross-country panel data analysis. Journal of Comparative Economics, 37 (3), 432-452.

[16] Ding, S. and Knight, J. (2011). Why has China grown so fast? The role of physical and human capital formation. Oxford Bulletin of Economics and Statistics, 73 (2). pp. 141-174.

[17] Martin, R. and Sunley, P. (1998). Slow Convergence? The New Endogenous Growth Theory and Regional Development. Economic Geography, 74(3), pp. 201-227.

[18] Villaverde, J. and Maza, A. (2011). Globalisation, Growth and Convergence. The World Economy.

[19] Drezner, D. W. (2001). Globalization and Policy Convergence. International Studies Review, 3(1), pp. 53-78.

[20] Blank, R. and Burau, V. (2006). Setting Health Priorities across Nations: More Convergence than Divergence? Journal of Public Health Policy, 27(3), pp. 265-281.

[21] Li, Q. and Reuveny, R. (2003). Economic Globalization and Democracy: An Empirical Analysis. British Journal of Political Science, 33(1), pp. 29-54.

[22] Achterberg, P. and Yerkes, M. (2009). One welfare state emerging? Convergence versus divergence in 16 western countries. Journal of Comparative Social Welfare, 25(3), pp. 189-201.

[23] Khanna, T. and Palepu, K. G. (2004). Globalization and Convergence in Corporate Governance: Evidence from Infosys and the Indian Software Industry. Journal of International Business Studies, 35(6), pp. 484-507.

[24] Dreher, A., Sturm, J. E. and Ursprung, H. W. (2008). The Impact of Globalization on the Composition of Government Expenditures: Evidence from Panel Data. Public Choice, 134(3/4), pp. 263-292.

[25] Mishkin, F. S. (2007). Is Financial Globalization Beneficial? Journal of Money, Credit and Banking, 39(2/3), pp. 259-294.

[26] Douglas, S. P. and Craig, C. S. (2011). Convergence and Divergence: Developing a Semiglobal Marketing Strategy. Journal of International Marketing, 19(1), pp. 82-101.

[27] Hay, C. (2004). Common Trajectories, Variable Paces, Divergent Outcomes? Models of European Capitalism under Conditions of Complex Economic Interdependence. Review of International Political Economy, 11(2), pp. 231-262. 